\title{
Agriculture \& Food Security: first anniversary
}

\author{
Malcolm Elliott ${ }^{1 *}$, Molly Jahn ${ }^{2}$ and Magdy Madkour ${ }^{3}$
}

\section{Anniversary editorial}

We are delighted to celebrate the first anniversary of Agriculture \& Food Security with you, our readers. In our Launch Editorial [1] we highlighted the crucial role of agriculture in delivering improved food security to a global population that will reach ten billion by the end of the century, while maintaining biodiversity and other critical ecosystems services. This global challenge must confront the problems of climate change, recognizing that agricultural greenhouse gas emissions must be managed as much as possible, while using fewer natural resources and producing improved outcomes in human dimensions. Clearly this will require new knowledge-intensive processes, which are rapidly developed, rigorously tested and widely disseminated. In these causes we have emphasized the advantages of publishing in Agriculture \& Food Security which, as an open access journal, provides unrestricted access to research workers, decision makers and lay people around the world. Clearly, open access gives publications a worldwide audience far larger than any subscription-based journal so as to increase the visibility and impact of published work and comply with new commitments in major international research organizations. Our journal also enhances indexing and retrieval while eliminating the need for permission to reproduce and distribute material.

We are particularly grateful to the distinguished members of our Editorial Board [http://www.agricultureand foodsecurity.com/about/edboard] who have given their time to advise us on the way forward, and to participate, along with other experts, in the peer review process, which has ensured that our publications are of very high quality. Our community has welcomed Agriculture \& Food Security by submitting fine manuscripts for peer review and we have published twenty-six articles (comprising nine Research Papers, eight Reviews, six Commentaries and three Editorials, including Ademola Braimoh's Guest Editorial) along with a supplement on

\footnotetext{
* Correspondence: prof.m.elliott@gmail.com

${ }^{1}$ The Norman Borlaug Institute for Global Food Security, Leicester LE7 7JR, UK

Full list of author information is available at the end of the article
}

'Fostering innovation through building trust: Lessons from agricultural biotechnology partnerships in Africa', which was guest edited by Calestous Juma, Harvard University, and a thematic series on 'Climate smart agriculture' guest edited by Ademola Braimoh, of the World Bank.

The journal website [2] shows that many of our articles have been highly accessed. Our most highly viewed article, 'Food Security for Africa: an urgent global challenge' [3] by Albert Sasson has been accessed over 10,000 times to date. Other highly viewed articles include the Beddington et al. article 'The role for scientists in tackling food insecurity and climate change' [4] with over 9,500 accesses, and the Mba et al. article 'Re-orienting crop improvement for the changing climatic conditions of the $21^{\text {st }}$ Century' [5] with over 7,800 accesses. In addition to these highly accessed articles, the journal website has welcomed some 36,000 visitors to date.

Now, as we enter our second year, we look forward eagerly to publishing further research outcomes within the field of food security with a particular focus on research that may inform more sustainable agriculture and food systems that better address local, regional, national and/or global food and nutritional insecurity, as we set our sights on immediate and long-term sufficiency.

\section{Competing interests}

The authors declare that they have no competing interests.

\section{Author details \\ ${ }^{1}$ The Norman Borlaug Institute for Global Food Security, Leicester LE7 7JR, UK. ${ }^{2}$ Laboratory of Genetics and Department of Agronomy, Center for Sustainability and the Global Environment, University of Wisconsin-Madison, 3428 Genetics Biotechnology Center, 425 Henry Mall, Madison, WI 53706 USA. ${ }^{3}$ Arid Lands Agricultural Research Institute (ALARI), Faculty of Agriculture, Ain Shams University, P.O. Box 68, Hadayek Shobra, 11241 Cairo, Egypt.}

Received: 18 March 2013 Accepted: 19 March 2013 Published: 23 April 2013

\section{References}

1. Elliott MC, Jahn M, Madkour M: Welcome to Agriculture \& Food Security. Agr Food Secur 2012, 1:1.

2. Agriculture \& Food Security: http://www.agricultureandfoodsecurity.com/ mostviewed/alltime.

3. Sasson A: Food security in Africa: an urgent global challenge. Agr Food Secur 2012, 1:2.
C Biomed Central

(c) 2013 Elliott et al.; licensee BioMed Central Ltd. This is an Open Access article distributed under the terms of the Creative Commons Attribution License (http://creativecommons.org/licenses/by/2.0), which permits unrestricted use, distribution, and reproduction in any medium, provided the original work is properly cited. 
4. Beddington JR, Asaduzzaman M, Clark ME, Bremauntz A, Guillou MD, Jahn MM, Lin E, Mamo T, Negra C, Nobre CA, Scholes RJ, Sharma R, Van Bo N, Wakhungu J: The role for scientists in tackling food insecurity and climate change. Agr Food Secur 2012, 1:10.

5. Mba C, Guimaraes EP, Ghosh K: Re-orienting crop improvement for the changing climatic conditions of the $21^{\text {st }}$ Century. Agr Food Secur 2012, 1:7.

doi:10.1186/2048-7010-2-7

Cite this article as: Elliott et al: Agriculture \& Food Security: first anniversary. Agriculture \& Food Security 2013 2:7.

\section{Submit your next manuscript to BioMed Central and take full advantage of:}

- Convenient online submission

- Thorough peer review

- No space constraints or color figure charges

- Immediate publication on acceptance

- Inclusion in PubMed, CAS, Scopus and Google Scholar

- Research which is freely available for redistribution 